EXTENDED REPORT

\title{
Lamivudine is not effective in primary Sjögren's syndrome
}

\author{
B Gescuk, A J Wu, J P Whitcher, T E Daniels, S Lund, K Fye, J C Davis Jr
}

See end of article for

Ann Rheum Dis 2005;64:1326-1330. doi: 10.1136/ard.2004.031393

authors' affiliations

Correspondence to:

Dr John C Davis, Clinical

Trials Center, Division of

Rheumatology, University

of California, San

Francisco, 533 Parnassus

Avenue Box 0633 Room

U383, San Francisco, CA

94143-0633, USA;

jdavis@medicine.ucsf.edu

Accepted 7 February 2005

Published Online first

11 February 2005

Background: Retroviral infection has been implicated in the pathogenesis of primary Siögren's syndrome. Objective: To examine the efficacy of the reverse transcriptase inhibitor lamivudine in patients with this syndrome.

Methods: 16 patients with primary Sjögren's syndrome were randomised to receive either lamivudine $150 \mathrm{mg}$ twice daily or placebo for three months. Measures of lacrimal and salivary function, including minor salivary gland biopsies, were obtained before and after treatment.

Results: Treatment with lamivudine did not result in significant improvement in the primary outcome measure of unstimulated whole salivary flow or other secondary measures, including minor salivary gland biopsy focus scores.

Conclusion: Lamivudine is not effective in patients with primary Sjögren's syndrome, suggesting either that a retroviral aetiology is not present or that it may be important only in early disease.

$\mathrm{P}$ rimary Sjögren's syndrome is a chronic inflammatory autoimmune disease affecting mainly salivary and lacrimal glands. It results in xerostomia and keratoconjunctivitis sicca. The following evidence suggests that primary Sjögren's syndrome may be antigen driven: there is accumulation of mononuclear cells around epithelial cells in salivary tissue that are HLA-DR $+^{1-3}$; the majority of infiltrating lymphocytes in the labial salivary glands are $\mathrm{CD}^{+} \mathrm{T}$ cells $\mathrm{s}^{4-14}$; and there is clonal $\mathrm{T}$ cell proliferation in salivary tissue. ${ }^{15-17}$

Research suggests a role for retroviruses in the pathogenesis of Sjögren's syndrome. A Sjögren-like illness occurs in patients infected with human immunodeficiency virus $(\text { HIV })^{18}$ or HTLV-I. ${ }^{19-22}$ Thirty per cent of patients with primary Sjögren's syndrome produce antibodies to HIV p24 (gag) but not to other HIV proteins. ${ }^{23}{ }^{24}$ In lymphoblastoid cells exposed to homogenates of salivary tissue from patients with Sjögren's syndrome, an intracisternal A-type retroviral particle antigenically related to HIV was identified. ${ }^{25}$ Reverse transcriptase activity associated with anti-p24 positivity has also been detected in 30\% of patients with Sjögren's syndrome. ${ }^{24}$ Salivary glands also showed A-type like retroviral particles, suggesting the presence of an unknown retrovirus similar to HIV. ${ }^{24}$ In minor labial salivary glands, the tax gene-but not the gag, pol, or env genes-of HTLV-I was identified in two of nine patients with Sjögren's syndrome but not in controls. ${ }^{26}$ A sialadenitis similar to Sjögren's syndrome is seen in a HTLV-l-tax transgenic mouse. ${ }^{27}$

Based on these data, Steinfeld undertook an open label study evaluating the efficacy zidovudine (AZT) in seven patients with primary Sjögren's syndrome. ${ }^{28}$ Treatment resulted in improvement in both subjective and objective indices. We present our results of a placebo controlled, randomised, double blind study of lamivudine in primary Sjögren's syndrome.

\section{METHODS}

\section{Study support}

The study was funded by a private donation, the Arthritis Foundation of Northern California, Glaxo Welcome, and the
Rosalind Russell Medical Center for Arthritis Research. Glaxo Welcome also provided drug and placebo. None of the funding sources had influence on the study design, conduct, analysis, or manuscript preparation.

\section{Subjects and samples}

This was a single centre, randomised, double blind, and placebo controlled study in patients with primary Sjögren's syndrome. Subjects were recruited from the University of California, San Francisco (UCSF) affiliated rheumatology clinics and the private offices of rheumatologists throughout northern California. The protocol was approved by the UCSF Committee of Human Research and written informed consent was obtained from all patients. An investigational new drug application was filed with the Food and Drug Administration (IND No 37,158).

Subjects were required to be at more than 18 years of age, with primary Sjögren's syndrome diagnosed by the new American-European Consensus Group criteria. ${ }^{29}$ The enrolment period was from 1 September 2000 to l February 2003. Demographic details are given in table 1 . As the study began before publication of the new diagnostic criteria, initial study patients satisfied the older San Diego criteria. Later, the inclusion criteria were changed to incorporate the recommendations of the American-European Consensus Group. All previously enrolled patients met these new criteria. A methodological change in the new diagnostic criteria specified that the unstimulated whole salivary (UWS) flow measurement period should be 15 minutes. However, as patients entering the study before the publication of the new criteria were studied using a UWS measurement time of five minutes, the investigators decided to maintain this procedure to maintain consistency of the data.

All patients had a stimulated whole saliva flow of at least $0.04 \mathrm{ml} / \mathrm{min}$. There was a required 30 day washout period of cytotoxic drugs, decongestants, over the counter antihistamines, glucocorticoids, tricyclic antidepressants, mucolytic

Abbreviations: UWS, unstimulated whole salivary (flow); VAS, visual analogue scale 


\begin{tabular}{|c|c|c|c|c|}
\hline Patient & Control & SE & Lamivudine & SE \\
\hline Female & $100 \%$ & & $86 \%$ & \\
\hline Age (years) & 52.6 & 2.4 & 46.9 & 1.6 \\
\hline Disease duration (months) & 43.1 & 7.4 & 37.8 & 6.2 \\
\hline \multicolumn{5}{|l|}{ Drugs } \\
\hline NSAIDs & $29 \%$ & & $43 \%$ & \\
\hline Hydroxychloroquine & $14 \%$ & & $29 \%$ & \\
\hline \multicolumn{5}{|l|}{ Salivary gland histology } \\
\hline Focus score (foci/4 mm²) & 6.0 & 0.6 & 1.8 & 0.2 \\
\hline \multicolumn{5}{|l|}{ Other } \\
\hline No of eye drops/day & 27.7 & 8.2 & 25.6 & 5.8 \\
\hline Unstimulated whole saliva (g/5 $\mathrm{min}$ ) & 0.0367 & 0.0064 & 0.0963 & 0.0123 \\
\hline \multicolumn{5}{|l|}{ Laboratory tests } \\
\hline $\lg M R F$ titre $(U / \mathrm{ml})$ & 831.4 & 172.2 & 191.7 & 28.9 \\
\hline ANA titre & 411.4 & 31.9 & 462.9 & 43.2 \\
\hline SSA antibody positive & $71 \%$ & & $43 \%$ & \\
\hline SSB antibody positive & $43 \%$ & & $43 \%$ & \\
\hline CRP (mg/l) & 1.2 & 0.2 & 0.8 & 0.1 \\
\hline $\mathrm{ESR}(\mathrm{mm} / \mathrm{h})$ & 38.4 & 4.7 & 36.1 & 3.8 \\
\hline $\lg G(672-1760 \mathrm{mg} / \mathrm{dl})$ & 1724.0 & 84.6 & 1814.3 & 77.5 \\
\hline $\lg M(39-333 \mathrm{mg} / \mathrm{dl})$ & 184.4 & 14.2 & 147.1 & 12.9 \\
\hline $\lg A(89-581 \mathrm{mg} / \mathrm{dll})$ & 346.7 & 24.9 & 370.4 & 8.9 \\
\hline
\end{tabular}

agents, cholorectics, and secretagogues. The visual analogue scale (VAS) for oral dryness was required to be $\geqslant 25 \mathrm{~mm}$ (that is, suggesting at least mild xerostomia) at baseline. Patients were excluded for the following reasons:

- history of another autoimmune disease;

- pregnancy;

- treatment with chemotherapy or radiotherapy;

- history of HIV-1, HTLV-I, hepatitis (B or C) or active Epstein-Barr infection;

- malignancy within 5 years;

- other significant medical conditions affecting salivary or lacrimal function.

Patients were not permitted to undergo dental or medical procedures that could increase salivation or lacrimation during the course of the trial.

\section{Study drug and interventions}

Lamivudine is a synthetic nucleoside reverse transcriptase inhibitor that inhibits replication of human retroviruses by interfering with viral RNA directed DNA polymerase (reverse transcriptase). Lamivudine is used in combination with other antiretroviral agents in the treatment of HIV infection, and is approved for the treatment of hepatitis B. The study drug, supplied as tablets containing either $150 \mathrm{mg}$ of lamivudine or placebo, was given orally twice daily.

\section{Procedures}

Patients were randomly assigned to receive either lamivudine $150 \mathrm{mg}$ twice daily or placebo for 12 weeks. Randomisation occurred on a one to one basis, and the sequence followed a permuted block design (blocks of two and four). Random numbers generated by a commercial spreadsheet program assigned treatment within each block.

The primary outcome measure was UWS flow. Secondary outcomes included assessment of labial minor salivary gland focus score, stimulated parotid flow, tear production by way of an unanaesthetised Schirmer test (with open eyes), and the patient's perception of subjective variables related to the sensation of dry eyes and dry mouth and other symptoms associated with primary Sjögren's syndrome. Evaluation of salivary function was measured by collection of unstimulated whole and stimulated parotid salivary flow at baseline, weeks 4 and 12, and follow up (eight weeks after termination of treatment). Whole and parotid saliva samples were collected separately, each over five minutes. The methods of saliva collection have been reported previously. ${ }^{30-33}$ Evaluation of lacrimal function at baseline and at weeks 4 and 12 was carried out by the same clinician (JPW) using the unanaesthetised Schirmer tear test, rose bengal staining of corneal conjunctival epithelium, and tear break-up time test. Evaluation of lymphocytic infiltration of the labial minor salivary glands was undertaken by focus score analysis at baseline and week 12. The biopsy sample was obtained by the Daniels' technique. ${ }^{34}$ The samples were embedded in paraffin and sections cut through the middle of each gland. The severity of focal lymphocytic sialadenitis were graded according to a modified focus score procedure. ${ }^{35}$ A focus is an aggregate of 50 or more mononuclear cells, and the focus score is reported as the number of such aggregates per $4 \mathrm{~mm}^{2}$ of gland area. At least $20 \mathrm{~mm}^{2}$ of histological material from each patient was examined.

At each visit, subjects were instructed to provide a rating for 18 items using a $100 \mathrm{~mm}$ VAS (table 2; VAS1 to VAS18). Oral and physical examinations were carried out at each visit.

\section{Assays}

At baseline, patients were tested for HIV, HTLV I and II, hepatitis B and C, antinuclear antibodies, SS-A and SS-B antibodies, rheumatoid factor, creatinine kinase, thyroid stimulating hormone, complete blood count, chemistry panel, creatinine, liver function tests, amylase, albumin, immunoglobulin levels, urinalysis, erythrocyte sedimentation rate (ESR), and serum $C$ reactive protein. Certain haematological and serum profiles were repeated at weeks 4 and 12 .

\section{Statistical analysis}

Treatment comparisons were undertaken using the MannWhitney test or Fisher's exact test. Associations of age and 
Table 2 Changes from baseline to week 12

\begin{tabular}{|c|c|c|c|c|}
\hline Salivary/lacrimal flow & Control mean & SE & Lamivudine mean & SE \\
\hline Unstimulated whole ( $\mathrm{g} / 5 \mathrm{~min}$ ) & 0.0456 & 0.0154 & 0.0279 & 0.0103 \\
\hline Stimulated whole ( $\mathrm{g} / 5 \mathrm{~min})$ & 0.4377 & 0.1068 & 0.0179 & 0.0439 \\
\hline Right parotid (g/5 min) & -0.2599 & 0.0846 & -0.0413 & 0.0075 \\
\hline Left parotid $(\mathrm{g} / 5 \mathrm{~min})$ & -0.0021 & 0.0403 & -0.0430 & 0.0322 \\
\hline Right Schirmer (mm/5 min) & -2.9 & 0.3 & -0.8 & 0.5 \\
\hline Left Schirmer (mm/5 min) & -0.1 & 0.7 & -1.0 & 0.7 \\
\hline Right TBUT (s) & -0.9 & 0.8 & -0.2 & 0.7 \\
\hline Left TBUT (s) & -1.9 & 0.7 & -0.5 & 0.4 \\
\hline Right $R B$ staining & -0.4 & 0.1 & 0.0 & 0.0 \\
\hline Left RB staining & -0.3 & 0.1 & 0.0 & 0.0 \\
\hline Right fluorescein & -0.3 & 0.2 & -0.7 & 0.1 \\
\hline Light fluorescein & -0.2 & 0.2 & -0.7 & 0.1 \\
\hline \multicolumn{5}{|l|}{ Salivary gland histology } \\
\hline Focus score (foci $/ 4 \mathrm{~mm}^{2}$ ) & -1.8 & 0.6 & 0.3 & 0.3 \\
\hline \multicolumn{5}{|l|}{ Visual analogue scales* } \\
\hline VAS 1 & -27.0 & 3.6 & 4.6 & 3.9 \\
\hline VAS 2 & -13.0 & 4.6 & 2.1 & 2.7 \\
\hline VAS 3 & -9.6 & 1.4 & -2.1 & 1.7 \\
\hline VAS 4 & -0.6 & 2.6 & -0.4 & 3.7 \\
\hline VAS 5 & -2.1 & 3.1 & 3.7 & 4.0 \\
\hline VAS 6 & -15.7 & 3.3 & -18.6 & 2.3 \\
\hline VAS 7 & -11.1 & 3.7 & -11.9 & 3.0 \\
\hline VAS 8 & -6.1 & 3.0 & -3.7 & 2.0 \\
\hline VAS 9 & -8.3 & 3.0 & -4.9 & 2.1 \\
\hline VAS 10 & -6.3 & 3.8 & -4.6 & 3.6 \\
\hline VAS 11 & -4.4 & 3.9 & -16.3 & 5.7 \\
\hline VAS 12 & -5.4 & 4.5 & 2.0 & 9.2 \\
\hline VAS 13 & -10.0 & 5.1 & 4.4 & 3.1 \\
\hline VAS 14 & -2.3 & 3.4 & 2.6 & 2.7 \\
\hline VAS 15 & -4.9 & 2.9 & -1.7 & 1.8 \\
\hline VAS 16 & -4.6 & 2.4 & -9.5 & 3.3 \\
\hline VAS 17 & -10.1 & 2.6 & 5.7 & 1.1 \\
\hline VAS 18 & 5.6 & 4.0 & 3.7 & 1.4 \\
\hline \multicolumn{4}{|l|}{ Laboratory tests } & 1.4 \\
\hline CRP (mg/l) & 0.2 & 0.2 & 0.5 & 0.2 \\
\hline $\mathrm{ESR}(\mathrm{mm} / \mathrm{h})$ & -7.6 & 2.2 & 6.0 & 1.4 \\
\hline $\lg G(\mathrm{mg} / \mathrm{dl})$ & -84.0 & 25.0 & 113.3 & 24.1 \\
\hline $\lg M(\mathrm{mg} / \mathrm{dl})$ & -5.7 & 1.4 & 12.8 & 3.0 \\
\hline $\lg A(\mathrm{mg} / \mathrm{dl})$ & -16.4 & 3.4 & 22.7 & 5.4 \\
\hline \multicolumn{5}{|c|}{$\begin{array}{l}\text { VAS1-18: oral dryness, oral comfort, difficulty swallowing dry food without additional liquids, difficulty } \\
\text { swallowing any food without additional liquids, difficulty in speaking without drinking liquids, eye dryness, eye } \\
\text { burning, eye grittiness, eye foreign body sensation, energy level, arthralgias, myalgias, appetite, dry cough, nasa } \\
\text { dryness, vaginal dryness, skin dryness, and quality of sleep. } \\
\text { CRP, C reactive protein; ESR, erythrocyte sedimentation rate; RB, Rose-Bengal; TBUT, tear break up time. }\end{array}$} \\
\hline
\end{tabular}

disease duration with outcome measures were examined using Spearman correlations. An overall longitudinal analysis was carried out using a mixed model with fixed effects for time and treatment and random subject effect. The model included a time by treatment interaction and time was treated as a linear effect, with separate slopes estimated for each treatment group. Paired comparisons of time points within treatment groups were made using Wilcoxon signed ranks tests. Variables that were not normally distributed (for example, parotid and fluorescein) were dichotomised to zero or more than zero and analysed using general estimating equations. The model effects were the same as in the mixed model, but without the random subject effect.

\section{RESULTS}

In all, 210 patients were screened. Twenty two met eligibility criteria, and 17 were enrolled in the study (three declined participation). Three patients were dropped from the study after randomisation for protocol violations (sarcoidosis, malignancy, and non-compliance). Fourteen patients completed the study.

\section{Baseline characteristics}

Most of the patients were female (93\%) (table 1). The lamivudine patients had significantly higher baseline UWS $(p=0.0213$, table 2$)$ and lower minor salivary gland biopsy focus scores $(p=0.0087)$. The placebo patients had a greater degree of oral dryness as assessed by VAS $1 \quad(p=0.0298)$. There were no other significant differences at baseline.

\section{Baseline variables correlations}

There were no significant correlations of age with baseline variables. Disease duration was positively correlated with fluorescein ratings $(r=0.69, \mathrm{p}=0.0123)$ and negatively with Schirmer I measurements (left: $r=-0.55, \mathrm{p}=0.0405$; right: $r=-0.69, \mathrm{p}=0.0066$ ) and tear break up times (left: $r=-0.63, \mathrm{p}=0.0154$; right: $r=-0.5 \mathrm{l}, \mathrm{p}=0.0608$ ).

\section{Longitudinal analyses}

There were no significant changes in any salivary or lacrimal flow measurements or any VAS questions. No saliva collection values showed significant changes. Although focus scores decreased by 1.8 in the lamivudine group and increased by 0.3 in the placebo group, these changes were not significant.

Several laboratory measurements showed significant differences in time trends. The slope for the white blood count was -0.013 cells/l per week compared to 0.039 cells/l for placebo $(\mathrm{p}=0.0280)$. Blood urea nitrogen increased at a rate of $0.17 \mathrm{mg} / \mathrm{dl}$ per week for lamivudine patients compared with a $-0.018 \mathrm{mg} / \mathrm{dl}$ decrease for placebo $(\mathrm{p}=0.0370)$. Similarly, IgG increased at a rate of $4.46 \mathrm{mg} / \mathrm{dl}$ per week for 
lamivudine compared with a decrease of $-6.47 \mathrm{mg} / \mathrm{dl}$ for placebo $(\mathrm{p}=0.0059)$.

\section{DISCUSSION}

The underlying aetiological events leading to primary Sjögren's syndrome remain unknown. In contrast to the results of a pilot open label study using zidovudine, ${ }^{28}$ we were unable to show that lamivudine was effective in treating this condition, though we employed multiple measures of salivary and lacrimal function, eye staining, labial minor salivary gland focus scores, and VAS scores. The results of the earlier pilot study must be interpreted with caution owing to the significant placebo effect, ${ }^{36}$ especially when the outcomes are soft. ${ }^{37}$ This bias was present in other apparently positive open label drug studies involving hydroxychloroquine, ${ }^{38-42}$ ciclosporine, $^{43}{ }^{44}$ glucocorticoids, ${ }^{45} 46$ and infliximab ${ }^{47} 48$ in primary Sjögren's syndrome, the results of which were not validated by later placebo controlled studies. Additionally, differences in study design or inclusion criteria might account for the disparate results. The zidovudine study patients had to fulfil the European Community ${ }^{29}$ and the San Diego ${ }^{49}$ classification criteria for primary Sjögren's syndrome. The patients in our study had to fulfil the new American-European Consensus Group criteria. ${ }^{50}$ Based on different diagnostic criteria, some of the patients in the open study might not have qualified for this study. Also, patients in the zidovudine study were required to have evidence of active disease based on complaints of ocular and oral dryness, extraglandular symptoms, and the presence of an active inflammatory process, such as a raised ESR or hypergammaglobulinaemia. ${ }^{28}$ Not all of these were required in the lamivudine study and no patient has extraglandular features. Finally, the zidovudine patients had disease duration of less than one year, while the average disease duration in the lamivudine patients was 38 months. The lack of change in sicca symptoms and signs in the lamivudine study could reflect irreversible damage in glandular tissue in longstanding disease.

Pharmacokinetic profiles are unlikely to explain the different results, as lamivudine would be expected to be more effective. Lamivudine and zidovudine both inhibit reverse transcriptase; however, lamivudine has better bioavailability, higher potency, and a longer half life. ${ }^{51}$

There were small numbers of subjects in the study, and thus it might not have been powered to detect subtle differences. Our initial power calculation was based on the magnitude of change seen in the zidovudine study. In retrospect, this calculation should have included allowance for the relatively insensitive outcome measures, as studies of pilocarpine and cevelimine required much larger numbers. ${ }^{52-54}$

Unfortunately, validated activity indices and outcome measures are not available for trials of primary Sjögren's syndrome. ${ }^{55-57}$ Existing outcome measures such as salivary and lacrimal flow have significant variability even under well controlled conditions. Additionally, in the Canadian dry eye epidemiology study, $25 \%$ of surveyed patients reported dry eye symptoms, yet a lack of correlation between symptoms and objective measures, such as salivary and tear flow, was reported. ${ }^{98-60}$

Our study is one of the few to evaluate changes in minor labial salivary gland histology before and after treatment in a placebo controlled fashion. Although focus scores decreased in the lamivudine group and increased in the placebo group, the difference was not significant. The lack of effect could have reflected lower disease activity in the lamivudine group at baseline, as assessed by focus score, compared with the placebo group. A second possibility is that the study was not powered to show a significant difference. A third possibility involves the difficulty in using a histological outcome measure. Although biopsy of the exocrine glands shows inflammatory lymphocytic aggregates and, in later disease, acinar destruction, the correlation between the degree of inflammation or damage on biopsy and the degree of functional impairment of the glands leading to symptoms and signs of dry eyes and mouth is modest. ${ }^{61}{ }^{62}$ Consequently, measurement of glandular function by flow rates cannot be used to distinguish between the pathophysiological processes of inflammatory activity, acinar dysfunction, or acinar cell loss in the gland, any or all of which could be responsible for the functional impairment. ${ }^{57}$ Salivary gland biopsies are also subject to significant sampling bias. ${ }^{63}$

Lamivudine treatment did not result in improvement in 36 item short form health assessment questionnaire (SF-36) components. However, in another study, the SF-36 was unable to detect significant differences between subjects with primary Sjögren's syndrome and those with xerostomia, despite large differences in the unstimulated salivary flow rate between the two groups. ${ }^{64}$ Given the poor sensitivity of the SF-36, it may not be surprising that the instrument was unable to detect a difference.

This study does not provide evidence that inhibiting reverse transcriptase is effective in primary Sjögren's syndrome. Future research might examine a treatment in early disease and could be done in conjunction with retroviral testing on minor salivary gland biopsies and saliva.

\section{ACKNOWLEDGEMENTS}

We are indebted to Allison Webb, Anne Marie Duhme, Steve Lund, Maureen Fitzpatrick, Alan Bostrom, and Scott Fields. The study was supported by NIH/NIAMS 5K23/AR02113-02, the Arthritis Foundation of Northern California, Glaxo Welcome, and the Rosalind Russell Medical Center for Arthritis Research University of California San Francisco.

\section{Authors' affiliations}

B Gescuk, S Lund, K Fye, J C Davis, Division of Rheumatology, University of California, San Francisco, California, USA

A J Wu, J P Whitcher, T E Daniels, The Sjögren's Syndrome Clinic, University of California, San Francisco

\section{REFERENCES}

1 Hedfors $\mathrm{E}$, Lindahl G. Variation of MHC class I and II antigen expression in relation to lymphocytic infiltrates and interferon-gamma positive cells. J Rheumatol 1990; 17:743-50.

2 Fox RI, Bumol T, Fantozzi R, Bone R, Schreiber R. Expression of histocompatibility antigen HLA-DR by salivary gland epithelial cells in Sjogren's syndrome. Arthritis Rheum 1986;29:1105-11.

3 Lindahl G, Hedfors E, Klareskog L, Forsum U. Epithelial HLA-DR expression and T lymphocyte subsets in salivary glands in Sjogren's syndrome. Clin Exp Immunol 1985;61:475-82.

4 Adamson TC, Fox RI, Frisman DM, Howell FV. Immunohistologic analysis of lymphoid infiltrates in primary Sjogren's syndrome using monoclonal antibodies. J Immunol 1983; 130:203-8.

5 Zumla A, Mathur M, Stewart J, Wilkinson L, Isenberg D. T cell receptor expression in Sjogren's syndrome. Ann Rheum Dis 1991;50:691-3.

6 Anaya JM, Correa PA, Mantilla RD, Arcos-Burgos M. TAP, HLA-DQB1, and HLA-DRB 1 polymorphism in Colombian patients with primary Sjogren's syndrome. Semin Arthritis Rheum 2002;31:396-405.

7 Gottenberg JE, Busson M, Loiseau P, Cohen-Solal J, Lepage V, Charron D, ef al. In primary Sjogren's syndrome, HLA class II is associated exclusively with autoantibody production and spreading of the autoimmune response. Arthritis Rheum 2003;48:2240-5.

8 Guggenbuhl P, Jean S, Jego P, Grosbois B, Chales G, Semana G, et al. Primary Sjogren's syndrome: role of the HLA-DRB 1 ${ }^{*} 0301-{ }^{*} 1501$ heterozygotes. J Rheumatol 1998;25:900-5.

9 Hay EM, Thomas E, Pal B, Hajeer A, Chambers H, Silman AJ. Weak association between subjective symptoms or and objective testing for dry eyes and dry mouth: results from a population based study. Ann Rheum Dis 1998;57:20-4.

10 Kassan SS. Immunogenetics of Sjogren's syndrome. Ann Med Interne (Paris) 1998; 149:45-8.

11 Panchovska M, Sheitanov Y, Martinova F. Locus DR in primary Sjogren's syndrome. Bratisl Lek Listy 2001;102:382.

12 Sawada S, Sugai S, lijima S, Takei M, Paredes E, Hayama T, et al. Increased soluble CD4 and decreased soluble CD8 molecules in patients with Sjogren's syndrome. Am J Med 1992;92:134-40.

13 Tapinos NI, Polihronis M, Tzioufas AG, Skopouli FN. Immunopathology of Sjogren's syndrome. Ann Med Interne (Paris) 1998;149:17-24. 
14 Yamamoto K. Pathogenesis of Sjogren's syndrome. Autoimmun Rev 2003;2:13-18

15 Sasaki M, Nakamura S, Ohyama Y, Shinohara M, Ezaki I, Hara $\mathrm{H}$, et al. Accumulation of common T cell clonotypes in the salivary glands of patients with human T lymphotropic virus type l-associated and idiopathic Sjogren's syndrome. J Immunol 2000;164:2823-31.

16 Matsumoto I, Tsubota K, Satake Y, Kita Y, Matsumura R, Murata H, et al. Common $T$ cell receptor clonotype in lacrimal glands and labial salivary glands from patients with Sjogren's syndrome. J Clin Invest 1996;97:1969-77.

17 Sumida T, Matsumoto I, Maeda T, Nishioka K. T-cell receptor in Sjogren's syndrome. Br J Rheumatol 1997;36:622-9.

18 Couderc LU, Libera S, Klauss V, Goebel FD. Sicca complex and infection with human immunodeficiency virus. Arch Intern Med 1987;147:898-901.

19 Vernant JC, Buisson G, Magdeleine J, De Thore J, Jouannelle A, NeissonVernant $C$, et al. T-lymphocyte alveolitis, tropical spastic paresis, and Sjogren syndrome. Lancet, 1988;i, 177.

20 Eguchi K, Matsuoka N, Ida H, Nakashima M, Sakai M, Sakito S, et al. Primary Sjogren's syndrome with antibodies to HTLV-I: clinical and laboratory features. Ann Rheum Dis 1992;51:769-76.

21 Terada K, Katamine S, Eguchi K, Moriuchi R, Kita M, Shimada $\mathrm{H}$, et al. Prevalence of serum and salivary antibodies to HTLV-1 in Sjogren's syndrome. Lancet 1994;344:1116-19.

22 Tamiya S, Matsuoka M, Etoh K, Watanabe T, Kamihira S, Yamaguchi K, et al. Two types of defective human T-lymphotropic virus type I provirus in adult Tcell leukemia. Blood 1996;88:3065-73.

23 Talal N, Dauphinee MJ, Dang H, Alexander SS, Hart DJ, Garry RF. Detection of serum antibodies to retroviral proteins in patients with primary Sjogren's syndrome (autoimmune exocrinopathy). Arthritis Rheum 1990;33:774-81.

24 Yamano S, Renard JN, Mizuno F, Narita Y, Uchida Y, Higashiyama H, et al. Retrovirus in salivary glands from patients with Sjogren's syndrome. J Clin Pathol 1997;50:223-30.

25 Garry RF, Fermin CD, Hart DJ, Alexander SS, Donehower LA, Luo-Zhang H. Detection of a human intracisternal A-type retroviral particle antigenically related to HIV. Science 1990;250:1127-9.

26 Mariette X, Agbalika F, Daniel MT, Bisson M, Lagrange P, Brouet JC, et al. Detection of human $T$ lymphotropic virus type I tax gene in salivary gland epithelium from two patients with Sjogren's syndrome. Arthritis Rheum 1993;36:1423-8.

27 Green JE, Hinrichs SH, Vogel J, Jay G. Exocrinopathy resembling Sjogren's syndrome in HTLV-1 tax transgenic mice. Nature 1989;341:72-4.

28 Steinfeld SD, Demols P, Van Vooren JP, Cogan E, Appelboom T. Zidovudine in primary Sjogren's syndrome. Rheumatology (Oxford) 1999;38:814-17.

29 Vitali C, Bombardieri S, Moutsopoulos HM, Balestrieri G, Bencivelli W, Bernstein RM, et al. Preliminary criteria for the classification of Sjogren's syndrome. Results of a prospective concerted action supported by the European Community. Arthritis Rheum 1993;36:340-7.

30 Cummins MJ, Papas A, Kammer GM, Fox PC. Treatment of primary Sjogren's syndrome with low-dose human interferon alfa administered by the oromucosal route: combined phase III results. Arthritis Rheum 2003;49:585-93.

31 Atkinson JC, Travis WD, Pillemer SR, Bermudez D, Wolff A, Fox PC. Major salivary gland function in primary Sjogren's syndrome and its relationship to clinical features. J Rheumatol 1990;17:318-22.

32 Skopouli FN, Jagiello P, Tsifetaki N, Moutsopoulos HM. Methotrexate in primary Sjogren's syndrome. Clin Exp Rheumatol 1996;14:555-8.

33 Fox RI, Robinson CA, Curd JG, Kozin F, Howell FV. Sjogren's syndrome. Proposed criteria for classification. Arthritis Rheum 1986;29:577-85.

34 Daniels TE. Labial salivary gland biopsy in Sjogren's syndrome. Assessment as a diagnostic criterion in 362 suspected cases. Arthritis Rheum 1984;27:147-56.

35 Greenspan JS, Daniels TE, Talal N, Sylvester RA. The histopathology of Sjogren's syndrome in labial salivary gland biopsies. Oral Surg Oral Med Oral Pathol 1974; 37:217-29.

36 Abel U, Koch A. The role of randomization in clinical studies: myths and beliefs. J Clin Epidemiol 1999;52:487-97

37 Concato J, Shah N, Horwitz RI. Randomized, controlled trials, observational studies, and the hierarchy of research designs. N Engl J Med 2000;342:1887-92.

38 Kruize AA, Hene RJ, Kallenberg CG, van Bijsterveld OP, van der Heide A, Kater L, et al. Hydroxychloroquine treatment for primary Sjogren's syndrome: a two year double blind crossover trial. Ann Rheum Dis 1993;52:360-4.

39 Tishler M, Yaron I, Shirazi I, Yaron M. Hydroxychloroquine treatment for primary Siogren's syndrome: its effect on salivary and serum inflammatory markers. Ann Rheum Dis 1999;58:253-6.
40 Fox RI, Dixon R, Guarrasi V, Krubel S. Treatment of primary Sjogren's syndrome with hydroxychloroquine: a retrospective, open-label study. Lupus 1996;5(suppl 1):S31-6.

41 Manoussakis MN, Moutsopoulos HM. Antimalarials in Sjogren's syndrome the Greek experience. Lupus 1996;5(suppl 1):S28-30.

42 Fox RI, Chan E, Benton L, Fong S, Friedlaender M, Howell FV. Treatment of primary Sjogren's syndrome with hydroxychloroquine. Am J Med 1988:85:62-7.

43 Drosos AA, Skopouli FN, Galanopoulou VK, Kitridou RC, Moutsopoulos HM. Cyclosporin a therapy in patients with primary Sjogren's syndrome: results at one year. Scand J Rheumatol Suppl 1986;61:246-9.

44 Dalavanga YA, Detrick B, Hooks JJ, Drosos AA, Moutsopoulos HM. Effect of cyclosporin $A(C y A)$ on the immunopathological lesion of the labial minor salivary glands from patients with Sjogren's syndrome. Ann Rheum Dis 1987;46:89-92.

45 Miyawaki S, Nishiyama S, Matoba K. Efficacy of low-dose prednisolone maintenance for saliva production and serological abnormalities in patients with primary Sjogren's syndrome. Intern Med 1999:38:938-43.

46 Fox PC, Datiles M, Atkinson JC, Macynski AA, Scott J, Fletcher D, et al. Prednisone and piroxicam for treatment of primary Sjogren's syndrome. Clin Exp Rheumatol 1993;11:149-56

47 Steinfeld SD, Demols P, Salmon I, Kiss R, Appelboom T. Infliximab in patients with primary Sjogren's syndrome: a pilot study. Arthritis Rheum 2001;44:2371-5.

48 Mariette X, Ravaud P, Steinfeld S, Baron G, Goetz J, Hachulla E, et al. Inefficacy of infliximab in primary Sjogren's syndrome: results of the randomized, controlled Trial of Remicade in Primary Sjogren's Syndrome (TRIPSS). Arthritis Rheum 2004;50:1270-6.

49 Fox RI, Saito I. Criteria for diagnosis of Sjogren's syndrome. Rheum Dis Clin North Am 1994;20:391-407.

50 Vitali C, Bombardieri S, Jonsson R, Moutsopoulos HM, Alexander EL, Carsons SE, et al. Classification criteria for Sjogren's syndrome: a revised version of the European criteria proposed by the American-European Consensus Group. Ann Rheum Dis 2002;61:554-8.

51 Physician Desk Reference Online. Montvale, NJ: Thomas Healthcare, 20034 ..

52 Papas AS, Fernandez MM, Castano RA, Gallagher SC, Trivedi M, Shrotriya RC. Oral pilocarpine for symptomatic relief of dry mouth and dry eyes in patients with Sjogrens syndrome. Adv Exp Med Biol 1998;438:973-8.

53 Petrone D, Condemi JJ, Fife R, Gluck O, Cohen S, Dalgin P. A double-blind, randomized, placebo-controlled study of cevimeline in Sjogren's syndrome patients with xerostomia and keratoconjunctivitis sicca. Arthritis Rheum 2002;46:748-54.

54 Fife RS, Chase WF, Dore RK, Wiesenhutter CW, Lockhart PB, Tindall E, et al. Cevimeline for the treatment of xerostomia in patients with Sjogren syndrome: a randomized trial. Arch Intern Med 2002;162:1293-300.

55 Asmussen KH, Bowman SJ. Outcome measures in Sjogren's syndrome. Rheumatology (Oxford) 2001;40:1085-8.

56 Bowman SJ. Collaborative research into outcome measures in Sjogren's syndrome. Update on disease assessment. Scand J Rheumatol Suppl 2002;(116):23-7.

57 Bowman SJ, Pillemer S, Jonsson R, Asmussen K, Vitali C, Manthorpe R, et al. Revisiting Sjogren's syndrome in the new millennium: perspectives on assessment and outcome measures. Report of a workshop held on 23 March 2000 at Oxford, UK. Rheumatology (Oxford) 2001;40:1180-8.

58 Pflugfelder SC, Tseng SC, Sanabria O, Kell H, Garcia CG, Felix C, et al. Evaluation of subjective assessments and objective diagnostic tests for diagnosing tear-film disorders known to cause ocular irritation. Cornea 1998; 17:38-56.

59 Schein OD, Tielsch JM, Munoz B, Bandeen-Roche K, West S. Relation between signs and symptoms of dry eye in the elderly. A population-based perspective. Ophthalmology 1997; 104:1395-401

60 Tiplady B, Jackson SH, Maskrey VM, Swift CG. Validity and sensitivity of visual analogue scales in young and older healthy subjects. Age Ageing 1998;27:63-6.

61 Humphreys-Beher MG, Brayer J, Yamachika S, Peck AB, Jonsson R. An alternative perspective to the immune response in autoimmune exocrinopathy: induction of functional quiescence rather than destructive autoaggression. Scand J Immunol 1999;49:7-10.

62 Jonsson R, Kroneld U, Backman K, Magnusson B, Tarkowski A. Progression of sialadenitis in Sjogren's syndrome. Br J Rheumatol 1993;32:578-81.

63 Leroy JP, Pennec YL, Soulier C, Berthelot JM, Letoux G, Youinou P. Follow up study of labial salivary gland lesions in primary Sjogren's syndrome. Ann Rheum Dis 1992:51:777-80.

64 Rostron J, Rogers S, Longman L, Kaney S, Field EA. Health-related quality of life in patients with primary Sjogren's syndrome and xerostomia: a comparative study. Gerodontology 2002;19:53-9. 